\title{
Utjecaj prethodne terapije statinima na ishod liječenja sepse iz opće populacije
}

\section{The impact of prior statin therapy on the outcomes of community-acquired sepsis}

\author{
Iva Miškulin' , Marija Križić2, Marija Santini3, ${ }^{3,4}$ Bruno Baršicí,4 \\ ${ }^{1}$ Klinika za ženske bolesti i porode, Klinički bolnički centar Zagreb \\ ${ }^{2}$ Klinika za onkologiju, Klinički bolnički centar Zagreb, Zagreb \\ ${ }^{3}$ Klinika za infektivne bolesti „Dr. Fran Mihaljević, Zagreb \\ ${ }^{4}$ Medicinski fakultet Sveučilišta u Zagrebu
}

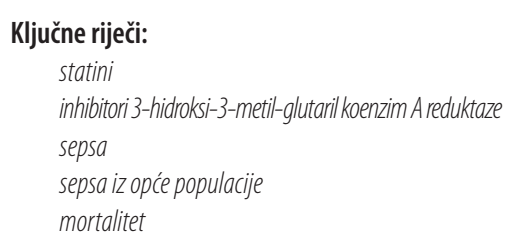

Keywords:

statins

3-hydroxy-3-methyl-glutaryl-CoA reductase inhibitors

sepsis

community-acquired sepsis mortality

Primljeno: 13-10-2019

Received: 13-10-2019

Prihvaćeno: 19-11-2019

Accepted: 19-11-2019

$\triangle$ Adresa za dopisivanje:

Iva Miškulin, dr. med.

Klinika za ženske bolesti i porode, Klinički bolnički centar Zagreb, Kišpatićeva 12, 10000 Zagreb

E-mail: iva.miskulin@gmail.com

\begin{abstract}
Sažetak
Usprkos znatnom napretku medicine smrtnost od sepse i danas je i dalje izrazito visoka. Stoga se ulažu velika sredstva u potrazi za novim lijekovima koji modificiraju upalni odgovor domaćina. Nakon provedenih eksperimentalnih istraživanja znanstvenici su dokazali protuupalna, imunomodulatorna i antikoagulacijska svojstva inhibitora 3-hidroksi-3-metil-glutaril koenzim A reduktaze, poznatijih pod nazivom statini, a koji se trenutno koriste za kontrolu hiperlipidemije i smatraju se korisnim u prevenciji kardiovaskularnih bolesti. Proveli smo sustavni pregled do sada objavljene literature o povezanosti prethodne uporabe statina sa smrtnošću i drugim kliničkim ishodima sepse iz opće populacije. Pretragom baze podataka PubMed pronađeno je osamnaest istraživanja, dvanaest kohortnih (pet prospektivnih, sedam retrospektivnih), pet randomiziranih kliničkih pokusa i jedno slučaj-kontrola istraživanje. Osam istraživanja ukazuju na povezanost prethodne uporabe statina i smanjene smrtnosti sepse, dok deset radova negira tu povezanost. lako neke studije sugeriraju da statini imaju pozitivnu ulogu u liječenju bolesnika sa sepsom, većina takvih studija su retrospektivna i imaju metodoloških ograničenja. Zbog toga smatramo da su potrebne veće randomizirane kliničke studije koje bi omogućle donošenje konkretnih zaključaka o uvođenju terapije statinima u kliničku praksu liječenja sepse.
\end{abstract}

Abstract

Despite considerable progress in medicine, mortality from sepsis is still extremely high. Therefore, great efforts are being made in the search for new drugs that modify immune response of the host. Scientists have shown anti-inflammatory, immunomodulatory and anticoagulant properties of the 3-hydroxy-3-methyl-glutaryl coenzyme A reductase inhibitors, known as statins, which are currently used for the control of hyperlipidemia, and are considered to be useful in the prevention of cardiovascular disease. We conducted a systematic review of the published literature examining the effect of previous statin treatment on mortality and other clinical outcomes in patients with community-acquired sepsis. Searching our database PubMed we found eighteen studies, twelve of them cohort (five prospective and seven retrospective), five randomized clinical trials, and one case-control. Eight studies indicate that there is a correlation between prior statin use and reduced sepsis mortality, while the other ten studies deny that correlation. Although some research suggest that statins may have a positive role in the treatment of patients with sepsis, most of these studies are retrospective and have methodological limitations. Therefore, we consider that larger randomized clinical trial studies are needed to enable concrete conclusions to be drawn about the introduction of statin therapy into the clinical practice of sepsis treatment.

\section{Uvod}

Sepsa se smatra jednim od vodećih uzroka mortaliteta $\mathrm{u}$ hospitaliziranih pacijenata (na desetom mjestu svih uzroka smrtnosti) ${ }^{[1]}$, a godišnje se u svijetu registrira oko 18 milijuna novih slučajeva ${ }^{[2]}$. Razlog navedenom stanju vjerojatno su povećanje dugovječnosti ljudi s kroničnim bolestima, porast invazivnih postupaka i širenje uporabe imunosupresivnih lijekova i kemoterapeutika ${ }^{[3]}$.
Današnje smjernice za liječenje sepse oslanjaju se na antimikrobnu terapiju i intenzivno liječenje $\mathrm{e}^{[4]}$. Iako je postignut značajan napredak u liječenju pacijenata sa sepsom, smrtnost kod istih je i dalje ekstremno visoka ${ }^{[5]}$. Poznato je da se u sepsi aktiviraju različiti upalni procesi u prisutnosti bakterijskih toksina što rezultira sustavnim upalnim odgovorom organizma i oštećenjem tkiva i organd ${ }^{6]}$. Smatra se da je jedan dio nepovolj- 
nih ishoda posljedica pretjeranog upalnog odgovora ${ }^{[7]}$, oslobađanja brojnih proupalnih molekula ${ }^{[8]}$, generalizirane disfunkcije endotela krvnih žila ${ }^{[9]}$, i proširenja periferne vaskulature koja postaje permeabilna, što rezultira perifernim izljevom tekućine, hipotenzijom i hipoperfuzijom organa ${ }^{[10]}$. Upravo je to razlog zašto se danas ulažu velika sredstva $\mathrm{u}$ istraživanje lijekova s imunomodulatornim svojstvima, koji bi spriječili oslobađanje proupalnih molekula, a time ublažili kliničku sliku i smanjili mortalitet.

Tri-hidrokski-3-metil-glutaril koenzim A (HMGCoA) reduktaza inhibitori ili statini najpropisivanija su skupina lijekova u svijetu i značajno utječu na preživljenje kod bolesnika s kardiovaskularnim bolesti$\mathrm{ma}^{[11]}$. Uz to što smanjuju sintezu kolesterola i razinu LDL-a $^{[12]}$, statini imaju i druge farmakološke učinke, uključujući imunomodulatorna ${ }^{[13]}$, antioksidativna ${ }^{[14]}$ i antikoagulacijska svojstva ${ }^{[15]}$. Takva svojstva statina potakla su brojne rasprave kako oni mogu biti korisni u liječenju i prevenciji teške sepse ${ }^{[6]}$.

Tijekom posljednja dva desetljeća proveden je velik broj istraživanja o učinku statina na pojavu i ishode raznih infekcija, a osobito sepse. Ova istraživanja su uglavnom opservacijska, metodološki heterogena, a njihovi rezultati kontradiktorni. Donošenje konačnih zaključaka o utjecaju statina na ishod liječenja infekcija ima brojna ograničenja prvenstveno zbog tzv. čimbenika posredne povezanosti. Najznačajniji mogući čimbenici posredne povezanosti su razlike u komorbiditetima između korisnika i nekorisnika statina, povezanost preventivnog uzimanja statina sa zdravim životnim stilom - tzv. „efekt zdravog korisnika”, razlike u primijenjenoj antimikrobnoj terapiji (izbor lijekova, „timing” primjene) te težini same bolesti.

Kako bismo ostvarili što bolji uvid u do sada objavljena istraživanja i donijeli zaključak o povezanosti terapije statinima i kliničke slike sepse odlučili smo napraviti njihov sustavni pregled s osobitim osvrtom na kontrolu gore navedenih čimbenika posredne povezanosti i drugih kontrolnih analiza.

\section{Metodologija}

Ovaj rad je sustavni pregled literature o utjecaju prethodne terapije statinima na ishod liječenja sepse iz opće populacije. Pretražena je elektronička baza podataka PubMed. Ključne riječi bile su: statin, sepsis i outcome. Rezultati su ograničeni na istraživanja na ljudima i engleski jezik. Uključili smo kohortna opservacijska istraživanja (prospektivno i retrospektivno), slučaj-kontrola studije i randomizirani klinički pokus. Isključili smo pregledne radove i meta-analizu, kao i radove na životinjama. Svi radovi su pretraženi i kritički evaluirani od strane dva istraživača (I.M i M.S).
Glavni kriteriji po kojima smo uključivali radove bili su odrasli bolesnici sa dijagnozom sepse iz opće populacije koji su prije hospitalizacije i postavljanja dijagnoze sepse primali bilo koji statin, u bilo kojoj dozi, kroz bilo koji vremenski period. Samo dva randomizirana dvostruko-slijepa placebo-kontrolirana istraživanja proučavala su trenutnu primjenu statina za vrijeme 28 -dnevne hospitalizacije ${ }^{[16,17]}$, bez prethodne uporabe statina.

Promatrani ishod liječenja u svakom istraživanju bio je bolnički mortalitet (30-dnevni, 60-dnevni ili 90-dnevni), dok su se ostali ishodi liječenja razlikovali od istraživanja do istraživanja, a uključili su: razvoj i progresiju teške sepse, prijem u JIL, dani provedeni u bolnici i JIL, mehanička ventilacija i terapija vazopresorima, razlika u koncentraciji IL-6, broj dana bez zatajenja organa, ponovna hospitalizacija u prvih 28 dana i u prvoj godini i te jednogodišnji mortalitet.

Da bismo mogli ocijeniti vrijednost ovih radova, usporediti njihove rezultate i konačno donijeti zaključak analizirali smo čimbenike posredne povezanosti. Grupirali smo ih na skupinu komorbiditeta, zatim „efekt zdravog korisnika”, prema razlici u pruženoj terapiji sepse i težini sepse. Zabilježili smo i uporabu skora sklonosti (engl. propensity score) zbog njegove značajnosti u kontroli čimbenika posredne povezanosti. Kako bi nam rezultati bili što vjerodostojniji u obzir smo uzeli različite kontrolne analize i argumente koji idu u prilog koristi statina ili protiv koristi statina.

Svjesni smo činjenice da ovo istraživanje ima brojna ograničenja po pitanju definicije izloženosti statinima, samog ishoda liječenja i čimbenika posredne povezanosti, zato statistička obrada rezultata u vidu meta-analize nije učinjena. Upravo zbog toga mi smo se bazirali što detaljnije usporediti i sistematizirati pojedina istraživanja i donijeti svoj sud o njihovoj vjerodostojnosti i kliničkoj važnosti.

Svi ključni podaci i rezultati sažeti su u dvije tablice radi lakšeg snalaženja i boljeg razumijevanja (Tablice 1 i 2).

\section{Rezultati}

Nakon detaljnog pretraživanja baze PubMed unosom ključnih riječi sepsis, statin i outcome od ponuđenih 165 istraživanja izdvojili smo osamnaest istraživanja koja su zadovoljila naše kriterije uključenja u ovaj rad. Sva istraživanja objavljena su od 2001. do 2018. god. Istraživanja obuhvaćaju vremenske periode od devet mjeseci do jedanaest godina. Od navedenih osamnaest istraživanja dvanaest ih je kohortnih (pet prospektivnih, sedam retrospektivnih), pet su randomizirani klinički pokusi, dok je jedan slučaj-kontrola. U kohortnim istraživanjima je uključeno od 120 do 52 
737 bolesnika, u randomiziranom kliničkom pokusu od 73 do 745 bolesnika, a u slučaj-kontrola 76 bolesnika. Pregled analiziranih radova prikazan je u Tablici 1.

Dvanaest istraživanja je kao konačan ishod promatralo samo kratkoročni mortalitet (30-dnevni, 60dnevni i unutarbolnički), četiri su promatrala kratkoročni i dugoročni (30-dnevni i 90-dnevni, 30-dnevni i 180-dnevni, te 30-dnevni i jednogodišnji), dok je jedan rad pratio samo dugoročni mortalitet (90-dnevni). Za razliku od navedenih sedamnaest, jedno istraživanje nije kao glavnu mjeru ishoda koristilo mortalitet nego progresiju sepse i prijem u jedinicu intenzivnog liječenja (JIL $)^{[18]}$. Ovo istraživanje je dokazalo da prethodna terapija statinima smanjuje progresiju sepse i prijem bolesnika u JIL. Kad pogledamo glavnu mjeru ishoda, mortalitet, iz Tablice 1 je vidljivo da deset od sedamnaest radova nije našlo povezanost između statina i smanjenog mortaliteta. Drugim riječima ova istraživanja ukazuju da statini nemaju utjecaj na smanjenje mortaliteta u pacijenata sa sepsom. Ostalih sedam istraživanja zaključuju da statini smanjuju mortalitet u pacijenata sa sepsom. Četiri od dvanaest istraživanja koja su promatrala kratkoročni mortalitet pokazuju korist statina. Među istraživanjima koja su promatrala mortalitet kratkoročno i dugoročno jedan $\mathrm{rad}^{[16]}$ nije dokazao utjecaj statina, drugi rad ${ }^{[19]}$ dokazao je smanjen 30-dnevni i 90-dnevni mortalitet kod korisnika statina, gdje je također proučavao razliku među statinima te dokazao superioran učinak atorvastatina $\mathrm{i}$ simvastatina nad rosuvastatinom. Ostala dva rada imaju oprečne rezultate; Thompsen i sur. ${ }^{[2,21]}$ su dokazali da statini ne utječu na 30-dnevnu smrtnost od bakterijemije, ali je dokazano da statini smanjuju 31-180 dnevnu smrtnost od bakterijemije, dok je drugo istraživanje ${ }^{[22]}$ dokazalo da statini utječu na 30-dnevni mortalitet, ali samo u pacijenata koji su bili na prethodnoj terapiji statinima za razliku od pacijenata koji su statine primali de novo, dok kod 90-dnevnog mortaliteta nema statistički značajnog rezultata u korist statina.

U Tablici 1 prikazane su i ostale mjere kliničkih ishoda kao što su razvoj i progresija teške sepse (dva istraživanja u korist statina, dva negiraju), zatim prijem i smrtnost u JIL (dva istraživanja u korist statina, posebno je značajno istraživanje Krugera i sur. iz 2013 koji su dokazali da de novo terapija statinima značajno skraćuje trajanje liječenja u JIL), ostala tri rada negiraju korist statina. Tri istraživanja promatrala su kao ishod trajanje bolničkog liječenja i sva tri negiraju korist statina. Zanimljiv podatak je i da su četiri istraživanja analizirala laboratorijske parametre i biomarkere upale upravo zbog potencijalnog djelovanja statina u modulaciji tih parametara. $U$ jednom istraživanju ${ }^{[22]}$ kao glavna mjera ishoda mjerila se koncentracija IL-6, a rezultati su pokazali da prethodna terapija statinima smanjuje koncentraciju IL-6 u sepsi, dok trenutna primjena atorvastatina nema takav učinak. Razlika u vrijednosti CRP-a tijekom hospitalizacije nije bila značajna između korisnika i nekorisnika. Drugo istraživanje ${ }^{[23]}$ ispitivalo je velik broj imunoloških i koagulacijskih markera kroz prvih sedam dana hospitalizacije, te je u korisnika statina samo antitrombinska aktivnost bila skromno povišena. U trećem istraživanju ${ }^{[24]}$ nisu našli značajnu razliku u CRP-u među grupama, dok je četvrto istraživanje ${ }^{[17]}$ dokazalo smanjenu koncentraciju upalnih parametara IL-1, Il-6, TNFa i CRP-a u atorvastatin grupi.

Rezultati kontrole mogućih čimbenika posredne povezanosti prikazani su u Tablici 2. Osim osnovnih demografskih podataka za koje su kontrole provedene u svim istraživanjima, ispitivana istraživanja su različito kontrolirana za utjecaj komorbiditeta, utjecaj tzv. „efekta zdravog korisnika”, za razlike u pruženoj terapiji sepse i s obzirom na težinu sepse.

Promatrajući komorbiditete uočeno je da su korisnici statina imali više pridruženih bolesti od kojih su najčešće bile kardiovaskularne bolesti, dijabetes, bolesti bubrega, jetrene bolesti i kronične plućne bolesti. Kako te bolesti utječu na mortalitet (glavnu varijablu svih istraživanja) i mogu ga povećati istraživači su provodili prilagodbu rezultata kako bi se smanjio utjecaj pridruženih bolesti na ishod. Najčešće je korišten CCI (Charlson Comorbidity indeks) koji uključuje 22 bolesti/stanja kojima pridružimo pacijentovu dob i na temelju rezultata procijeni se rizik za mortalitet ${ }^{[25]}$.

„Efekt zdravog korisnika” odnosi se na pridržavanje „zdravih” životnih navika i preventivnih mjera u razvoju neke bolesti, kao što je uzimanje lijekova (to se odnosi i na statine), redoviti posjeti liječniku, pravilna prehrana, tjelovježba, viši socioekonomski status, educiranost, što sve dovodi do unapređenja zdravlja. Ovaj model ponašanja čest je kod korisnika statina što može utjecati na mortalitet kao konačan ishod te navesti na pogrešan zaključak o postojanju povoljnog učinka samog lijeka ${ }^{[26,27]}$. Suprotno navedenom, pušenje, alkoholizam, imunosupresivna terapija, loš socioekonomski status, pretilost utječu na smanjeno preživljenje koje je češće kod nekorisnika statina, što može dovesti do pogrešnog zaključka o lošijem ishodu zbog nekorištenja statina, dok pravi razlozi mogu biti gore navedeni faktori ${ }^{[20,21]}$

Pet istraživanja statistički značajno dokazuju da su korisnici statina stariji i imaju više pridruženih bolesti poput hipertenzije, dijabetesa, CAD od nekorisnika, što bi moglo biti povezano sa većim mortalitetom. Nakon provedenih multivarijatnih analiza i prilagodbe čimbenika posredne povezanosti tri istraživanja ${ }^{[18,28,29]}$ navode statine nezavisnim čimbenikom povezanim $\mathrm{s}$ boljim preživljenjem i smanjenim prijemom $\mathrm{u}$ JIL, dok dva istraživanja ${ }^{[30,31]}$ statine nazivaju markerom uzna- 
predovale dobi i pridruženih komorbiditeta povezanih s lošim ishodom, no istodobno ih smatraju nezavisnom varijablom koja ne utječe na mortalitet.

Dio istraživanja proveo je analizu o broju pacijenata koji su primali antibiotsku terapiju u trenutku uključenja $\mathrm{u}$ istraživanje, te o adekvatnom izboru inicijalnog antibiotika, gdje nije bilo statistički značajnih razlika među grupama. Od ostalih lijekova najčešće su korišteni oni za kardiovaskularne bolesti (ACEI, aspirin, $\beta$-blokatori, diuretici), koji su značajno češće propisivani u grupi korisnika statina. Budući da navedeni lijekovi mogu utjecati na krajnji ishod („,efekt zdravog korisnika"), potrebno je provesti paralelne analize kako bi se isključio utjecaj čimbenika posredne povezanosti, što bismo mogli smatrati nedostatkom ovih istraživanja gdje takve analize nisu provedene. Izuzetak su Liappis i sur. ${ }^{[28]}$ gdje je multivarijatnom analizom dokazano da je korištenje ACEI povezano sa smanjenim preživljenjem, što može biti povezano sa korisnicima tih lijekova koji pate od kongestivnog srčanog zatajenja, koje je prediktor visokog mortaliteta u univarijatnoj analizi svih pacijenata. Zaključno, nije bilo razlike u učestalosti primjene ACEI između korisnika i nekorisnika, te je dokazana učinkovitost statina u smanjenju smrtnosti od sepse.

Kontrola parametra težine sepse ima ovdje nekoliko značenja. Za početak, gotovo sva istraživanja odredivala su težinu sepse kod hospitalizacije na temelju različitih bodovnih sustava (SOFA, APACHE II, SAPS II) i potrebe za primitkom u JIL. Četiri od osam istraživanja s „pozitivnim” rezultatom ${ }^{[18,29,32,33]}$ našli su povezanost između korištenja statina i boljeg preživljenja neovisno o težini sepse, tri istraživanja ${ }^{[19,20,28}$ nisu kontrolirali parametar težine sepse, dok je jedno istraživanje ${ }^{[16]}$ kao glavnu mjeru ishoda proučavalo progresiju sepse tijekom 28 dana (randomizirani klinički pokus) čiji rezultat je pokazao da trenutna primjena atorvastatina može prevenirati progresiju sepse. Nedostatak ovog istraživanja je da većina randomiziranih pacijenata nije bila kritično bolesna i imali su u startu nizak APACHE II zbroj, što je mogući čimbenik posredne povezanosti i u prethodna tri istraživanja. Ostalih deset istraživanja $s$ „negativnim” rezultatom nisu našli statističku značajnost uspoređujući težinu sepse. Izuzetak je rad Yanga i suradnika ${ }^{[34]}$ u kojem su nekorisnici u startu imali veći APACHE II zbroj, a težina sepse je bila jedini neovisni prediktor 30-dnevnog mortaliteta povezanog sa sepsom. Potreba za mehaničkom ventilacijom i inotropnim lijekovima kontrolirana je $\mathrm{u}$ samo pet istraživanja sa „negativnim” rezultatom ${ }^{[17,23,24,35,36]}$ i nije nađena razlika između korisnika i nekorisnika.

Iz Tablice 2 vidljivo je kako su, metodološki gledano istraživanja koja su dala negativne rezultate detaljnija (sva kontroliraju čimbenike komorbiditeta i zna- tan broj čimbenika vezanih uz učinak zdravog korisnika, a tri istraživanja radila su prilagodbu za skor sklonosti), za razliku od pozitivnih istraživanja kojima se kao nedostatak predbacuje mali broj pacijenata uključen $\mathrm{u}$ istraživanje i retrospektivnost.

Tri se rada ovdje ipak ističu zbog velikog broja pacijenata uključenih u istraživanje, a koji su bili na prethodnoj terapiji statinima ${ }^{[1,23,30]}$. Prva dva rada dala su negativan rezultat. Yende i suradnici ${ }^{[23]}$ promatrali su pacijente hospitalizirane zbog CAP i analizirali 90-dnevni mortalitet (uključujući i izvanbolnički), razvoj teške sepse, ali i velik broj biomarkera povezanih $s$ mogućim mehanizmima djelovanja statina. Nakon provedenih multivarijatnih analiza nije bilo statistički značajnog rezultata u korist statina. Ono po čemu se ovaj rad razlikuje od ostalih je da su pacijenti primarno bili hospitalizirani zbog pneumonije, a ne zbog sepse kao u svim ostalim istraživanjima. Budući da je razvoj teške sepse zajedno sa mortalitetom bio glavna mjera ishoda ovaj rad smo uključili u naše istraživanje. Od velikog je značenja rad Lee i suradnika ${ }^{[19]}$ jer se radi o velikom uzorku pacijenata gdje su svi korisnici statina podijeljeni u podgrupe prema vrsti statina koji su koristili (simvastatin, atorvastatin i rosuvastatin) gdje je dokazan manji mortalitet u grupi korisnika, te veći antibakterijski potencijal atorvastatina i simvastatina u odnosu na rosuvastatin.

Poseban značaj ovog istraživanja je što smo uključili pet randomiziranih, dvostruko-slijepih kliničkih pokusa. Kruger i sur. ${ }^{[22,32]} \mathrm{u}$ dva navrata su provodili istraživanje i promatrali utjecaj trenutne primjene $20 \mathrm{mg}$ atorvastatina i dobili oprečne rezultate. U prvom nisu dokazali korist kod trenutne primjene pacijenata na prethodnoj terapiji, dok su u drugom istraživanju dokazali korist. Treće istraživanje ${ }^{[16]}$ dokazalo je da trenutna primjena $40 \mathrm{mg}$ atorvastatina smanjuje progresiju sepse, ali ne utječe na mortalitet. Četvrto istraživanje ${ }^{[24]}$ dokazalo je da terapija rosuvastatinom kod bolesnika ne smanjuje unutarbolničku smrtnost niti ima utjecaj na ostale pozitivne ishode kod bolesnika na prethodnoj terapiji statinima kao i kod de novo terapije. Peto istraživanje ${ }^{[17]}$ proučavalo je trenutnu primjenu $40 \mathrm{mg}$ atorvastatina, gdje nije bilo razlike u mortalitetu između skupina, ali je dokazana smanjena koncentracija upalnih parametara $\mathrm{u}$ atorvastatin grupi. Nedostatak „pozitivnih” randomiziranih istraživanja je što bolesnici nisu bili teško bolesni i u startu su imali niži APACHE II zbroj. Također ostaju nepoznate optimalne doze statina koje bi bile potencijalno korisne kod kritično bolesnih jer su sva istraživanja primjenjivala niske doze statina zbog straha od toksičnosti i nuspojava. Nijedno istraživanje nije zabilježilo nuspojave.

Ova i ostala zapažanja i argumenti pojedinih autora navedeni su u Tablicama 1 i 2. 


\begin{tabular}{|c|c|c|c|c|c|c|c|}
\hline 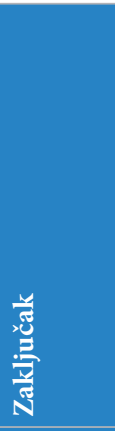 & 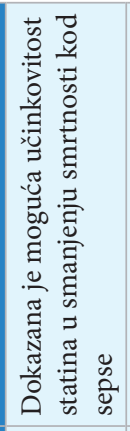 & 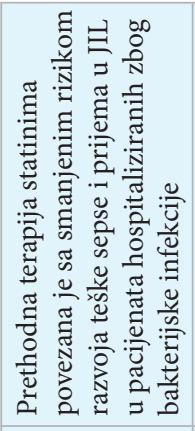 & 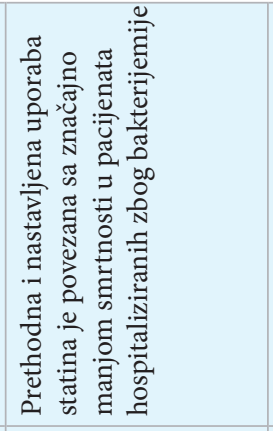 & 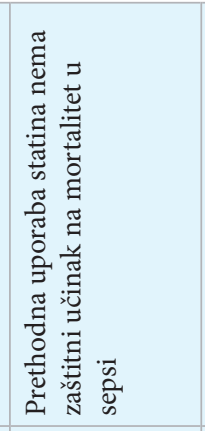 & 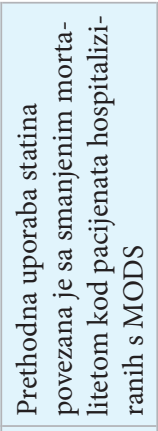 & 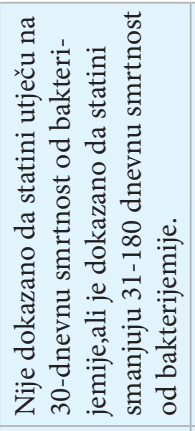 & 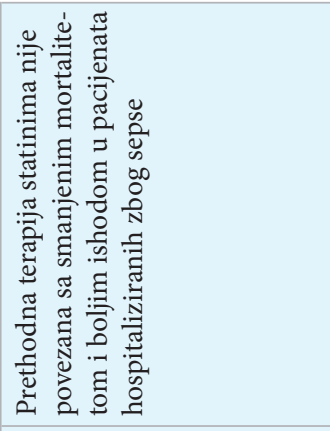 \\
\hline 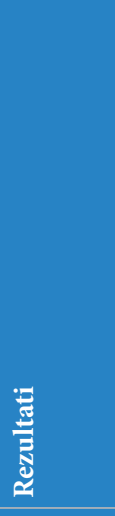 & 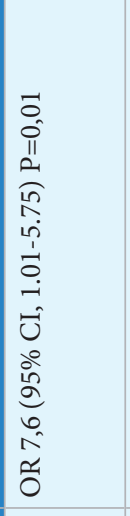 & 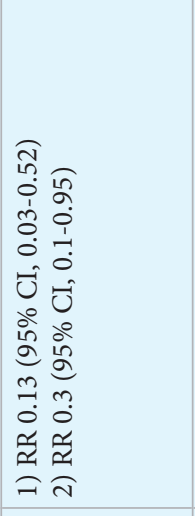 & 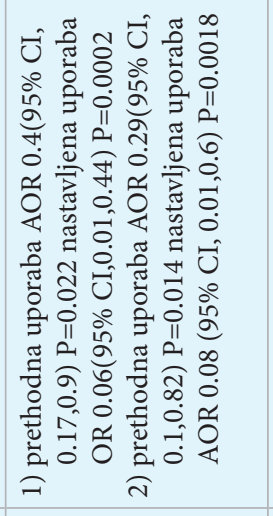 & 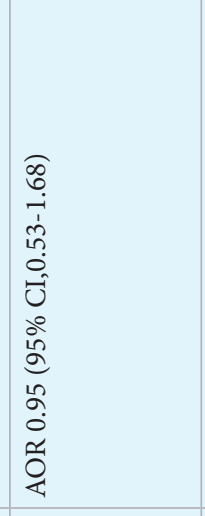 & 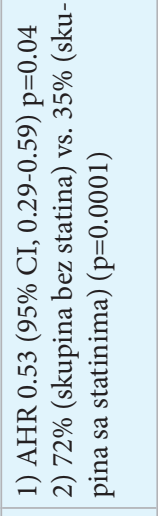 & 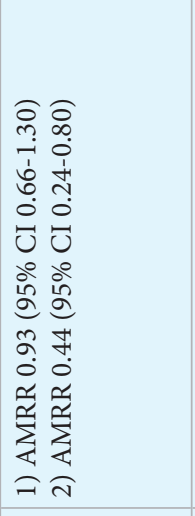 & 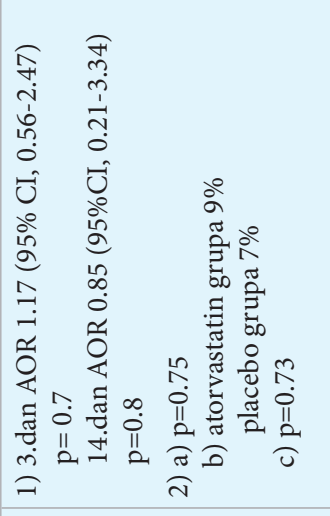 \\
\hline $\begin{array}{l}= \\
\frac{0}{0} \\
\frac{0}{9} \\
\end{array}$ & 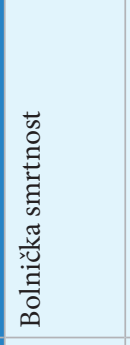 & 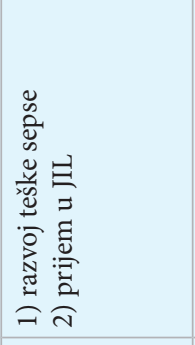 & 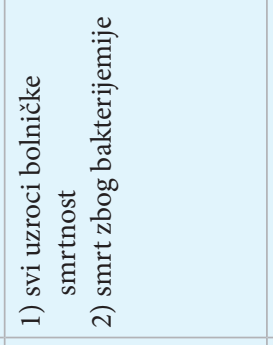 & 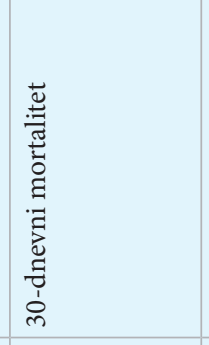 & 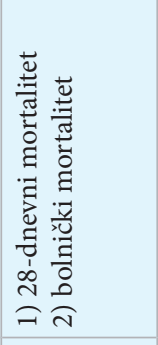 & 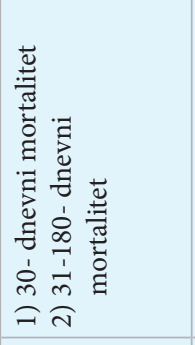 & 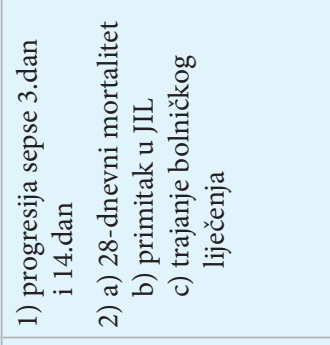 \\
\hline 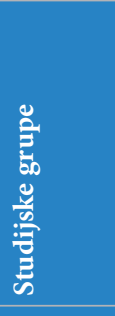 & 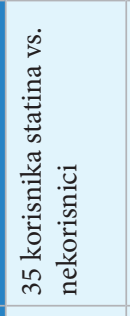 & 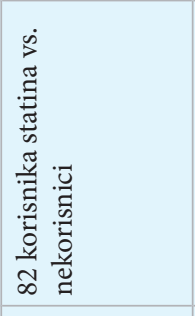 & 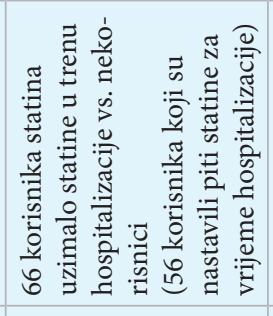 & 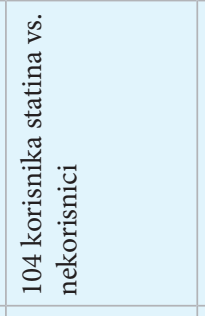 & 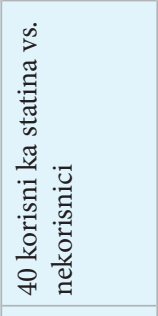 & 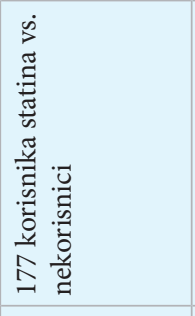 & 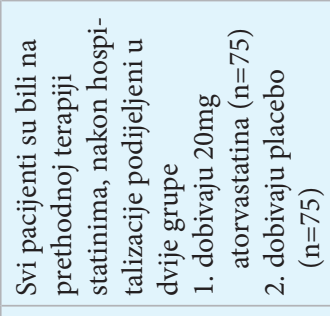 \\
\hline 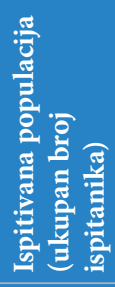 & 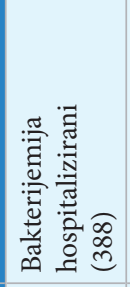 & 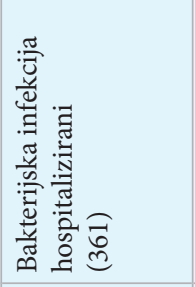 & 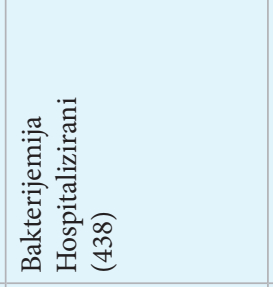 & 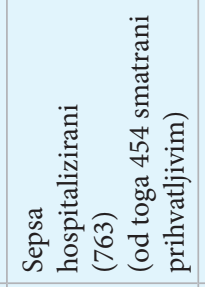 & 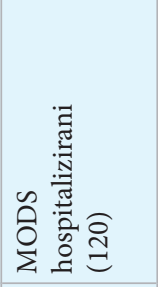 & 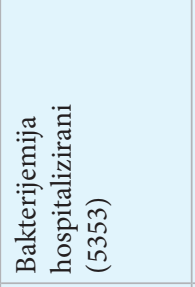 & 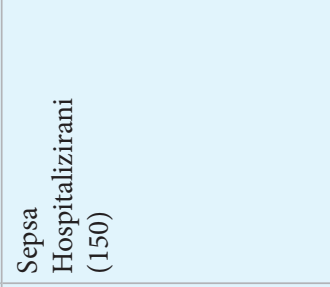 \\
\hline 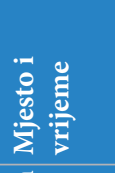 & 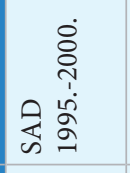 & 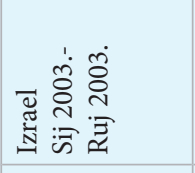 & 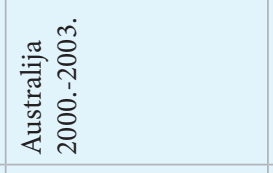 & 离 & 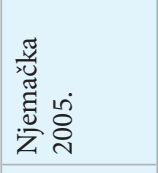 & 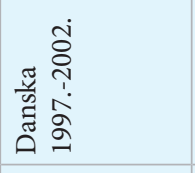 & 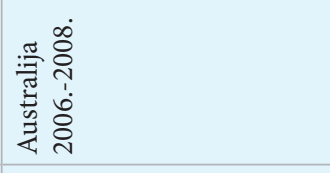 \\
\hline 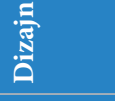 & 光 & 光 & בै & $\ddot{x}$ & 르 & 光 & $\underset{x}{E}$ \\
\hline 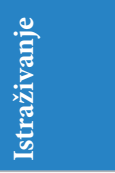 & 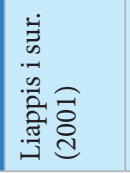 & 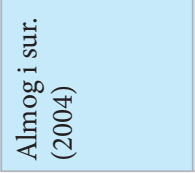 & 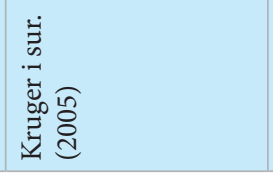 & 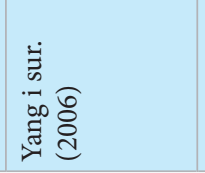 & 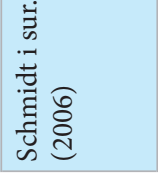 & 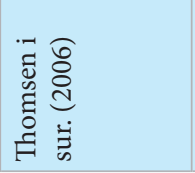 & 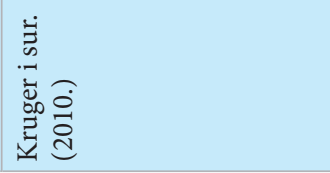 \\
\hline
\end{tabular}




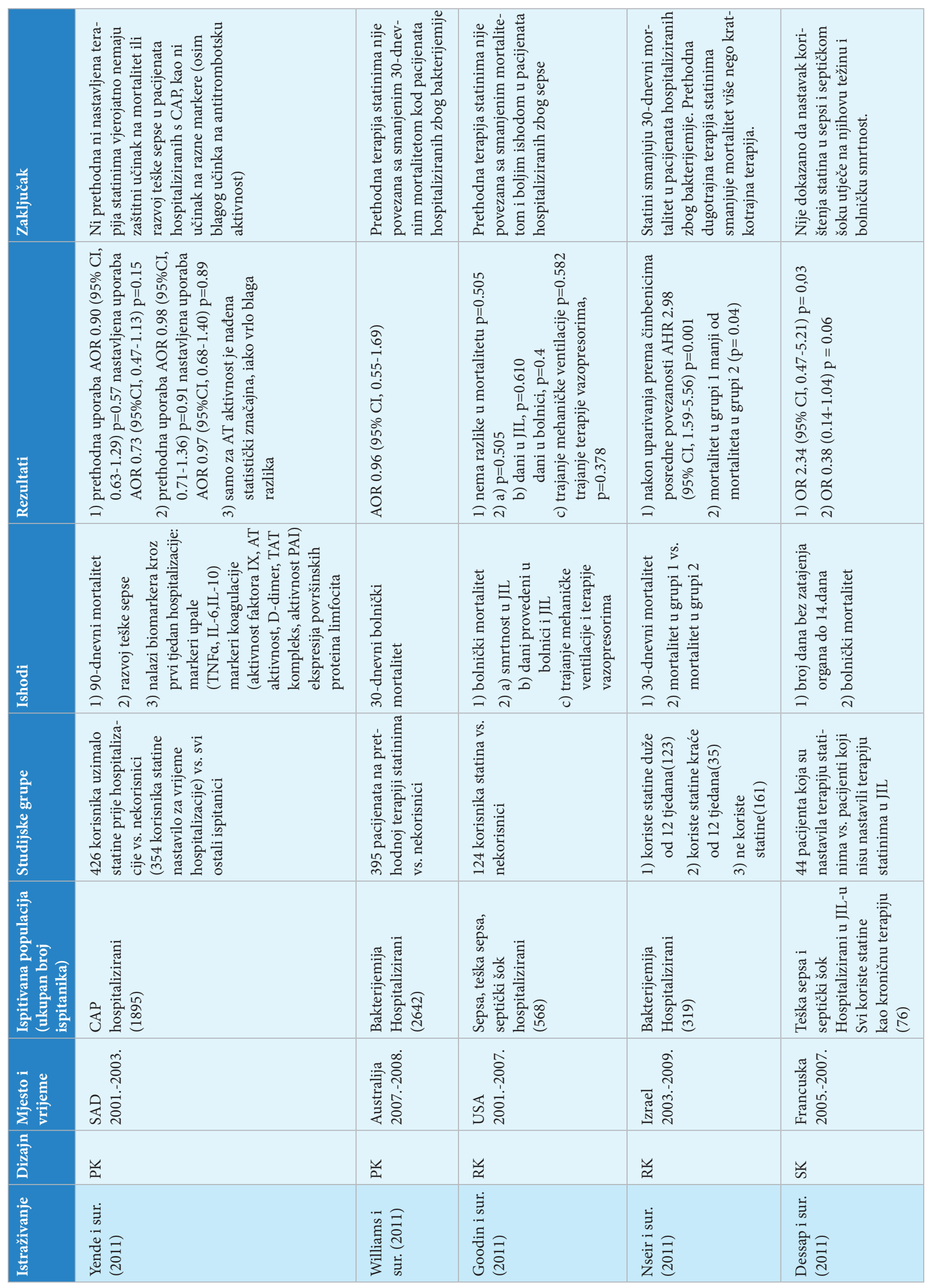




\begin{tabular}{|c|c|c|c|}
\hline & 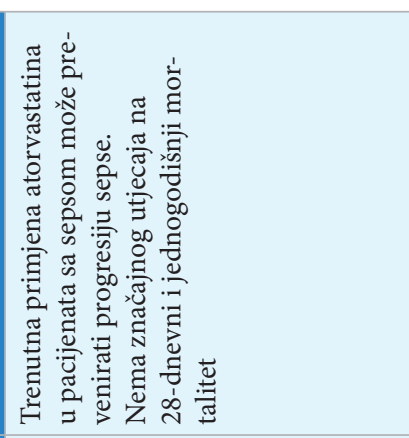 & 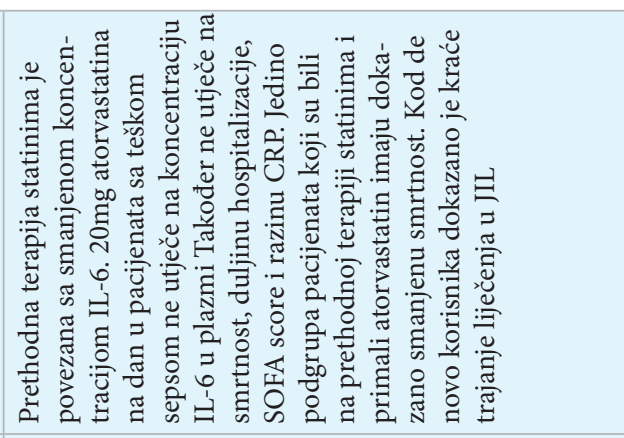 & 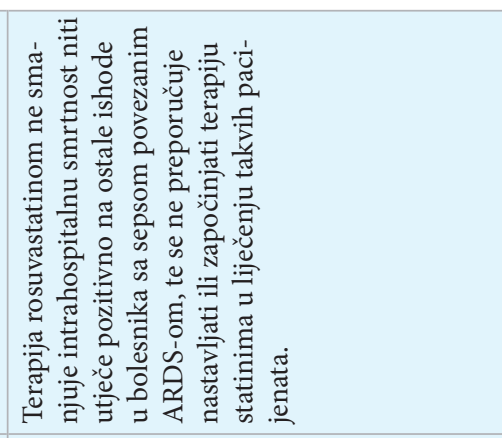 \\
\hline & 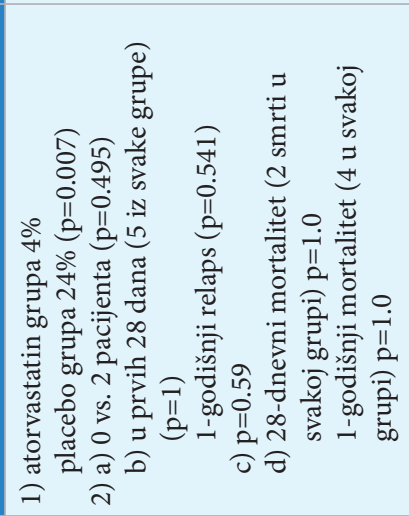 & 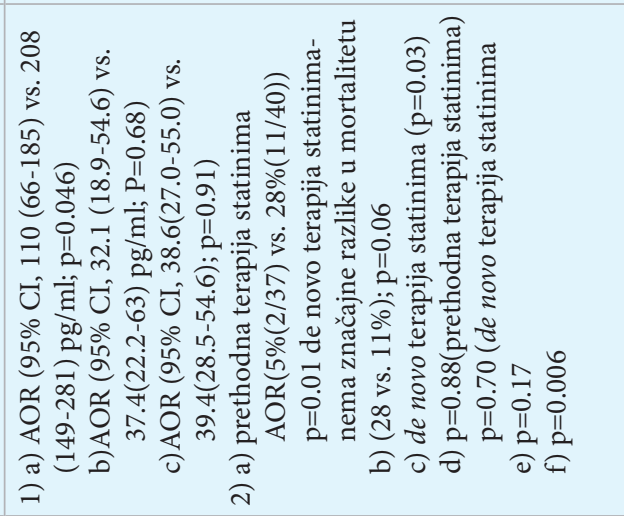 & 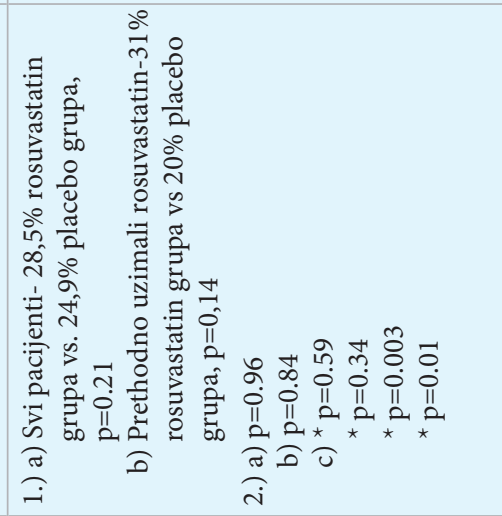 \\
\hline $\begin{array}{l}70 \\
\frac{0}{9} \\
\frac{0}{9}\end{array}$ & 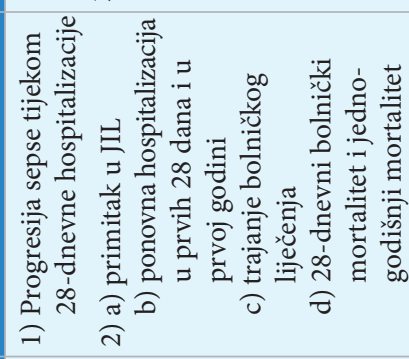 & 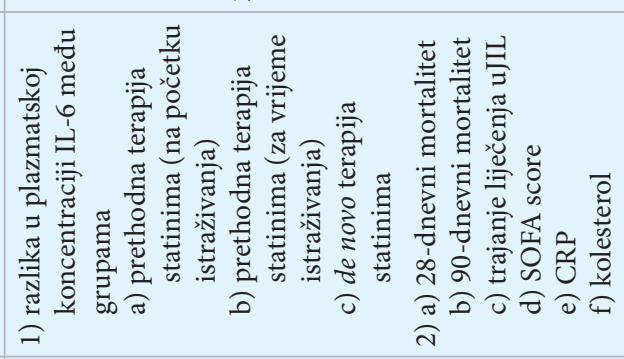 & 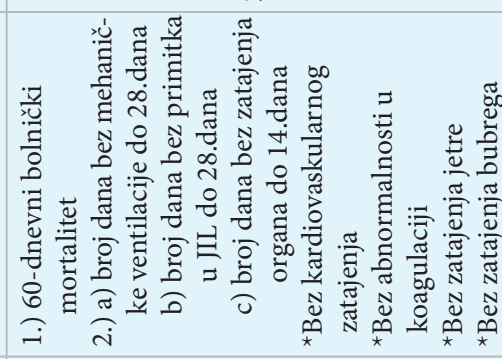 \\
\hline & 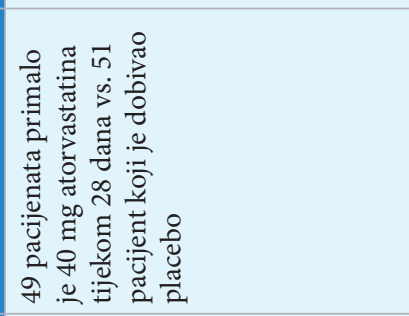 & 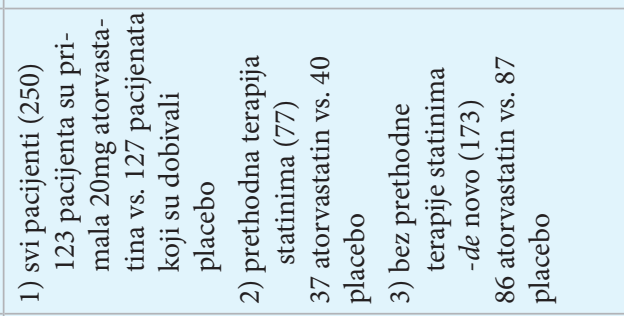 & 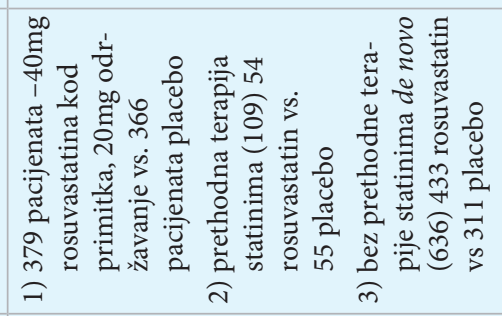 \\
\hline 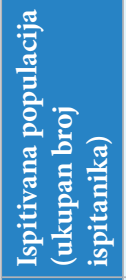 & 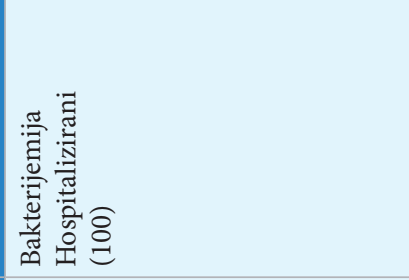 & 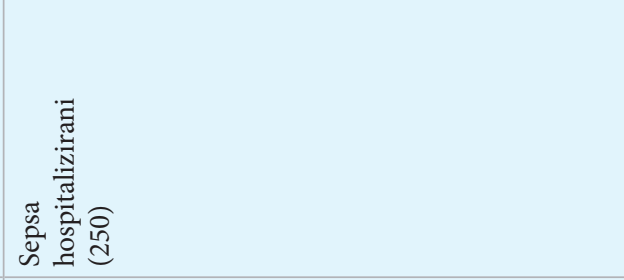 & 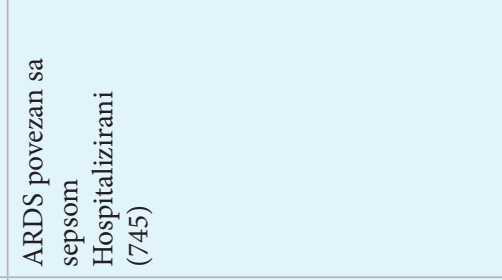 \\
\hline $\begin{array}{l}\overline{0} \\
\overline{0} \\
\stackrel{3}{\vec{z}}\end{array}$ & 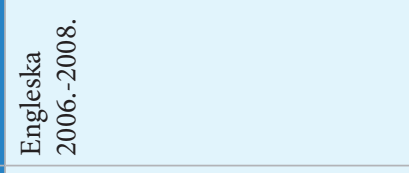 & 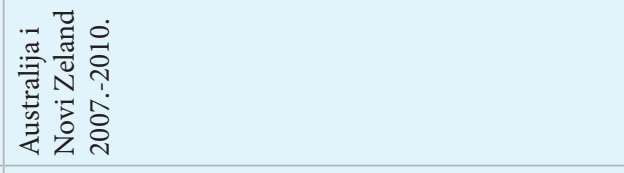 & 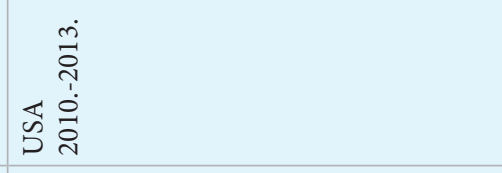 \\
\hline 氧 & $\underline{\mathscr{\varkappa}}$ & $\underset{\mathscr{A}}{\hat{y}}$ & $\underset{\mathscr{A}}{y}$ \\
\hline & 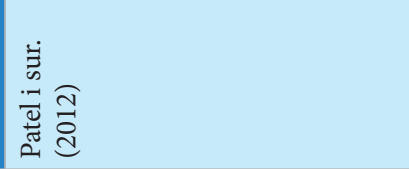 & 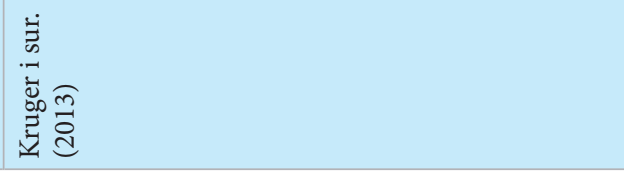 & 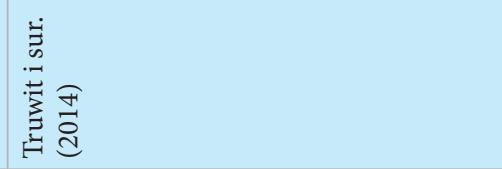 \\
\hline
\end{tabular}



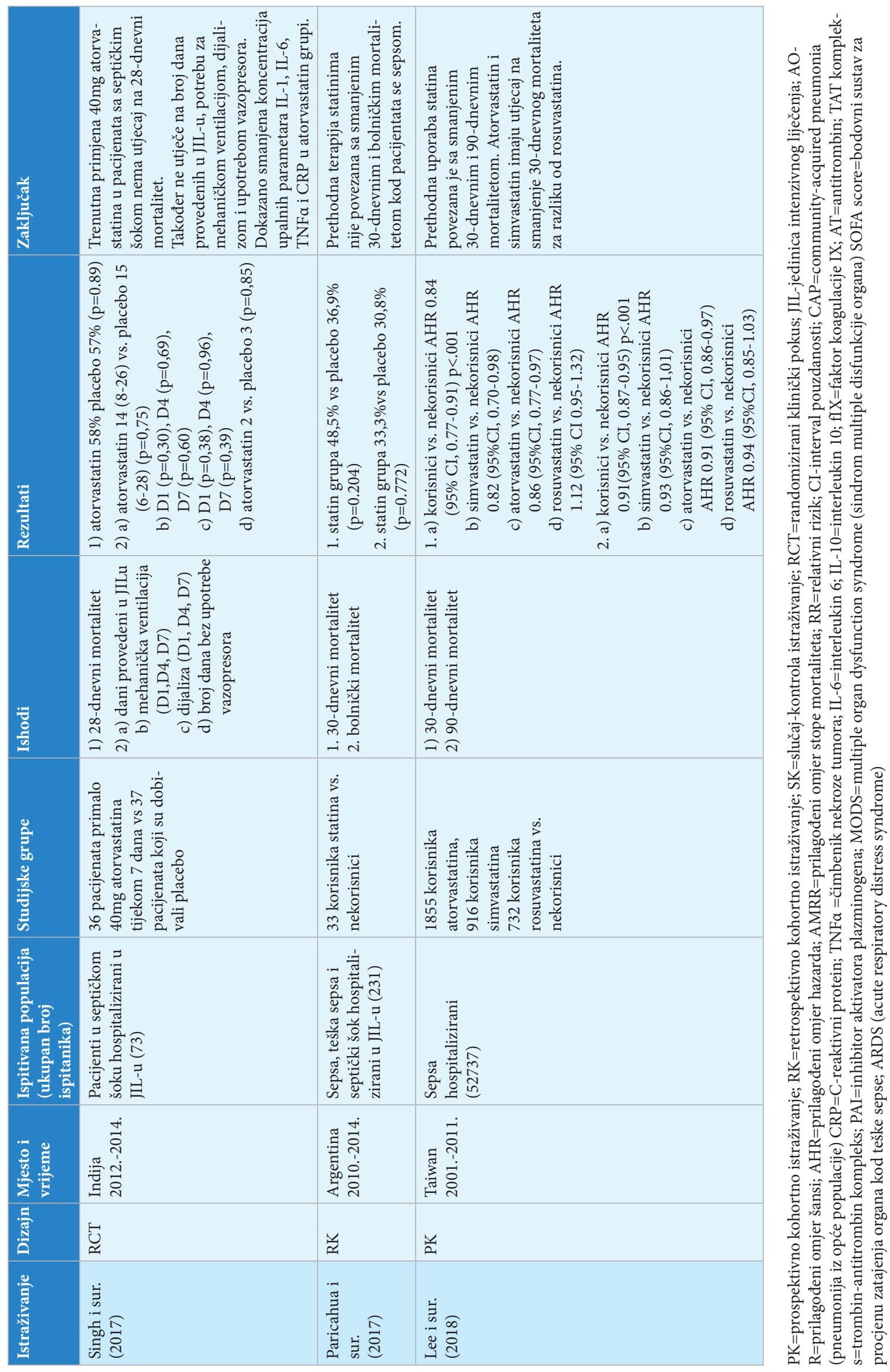


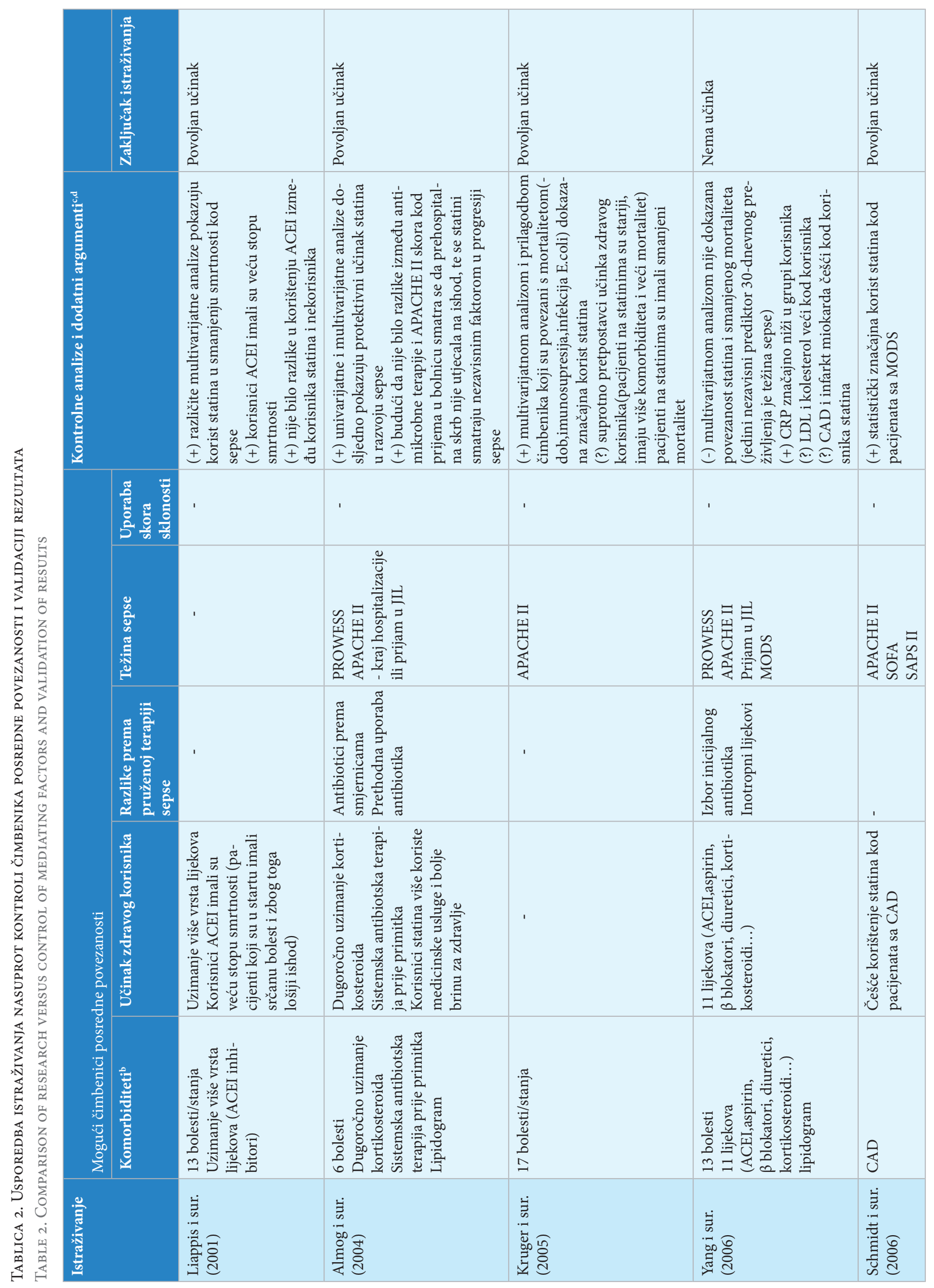




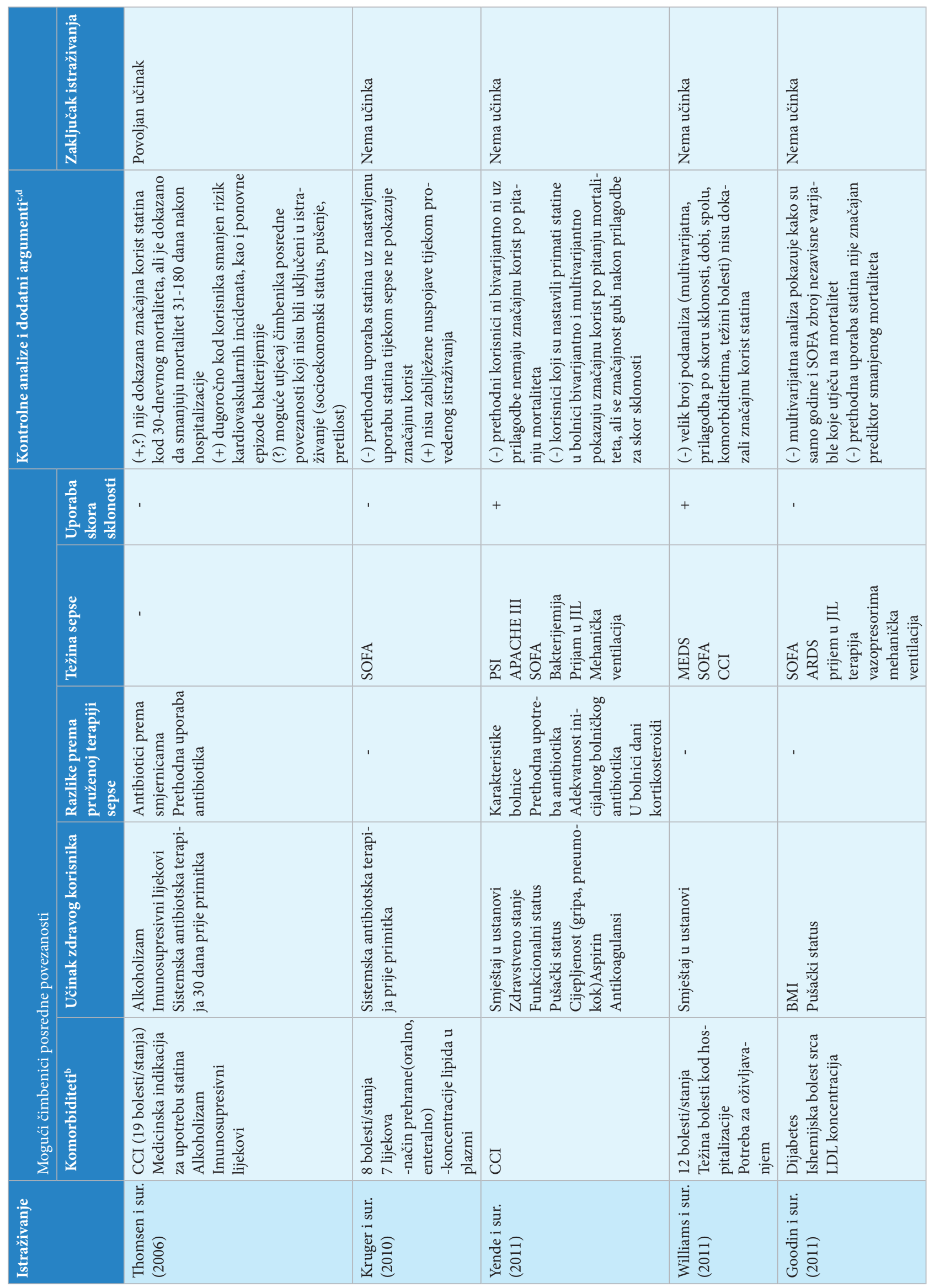




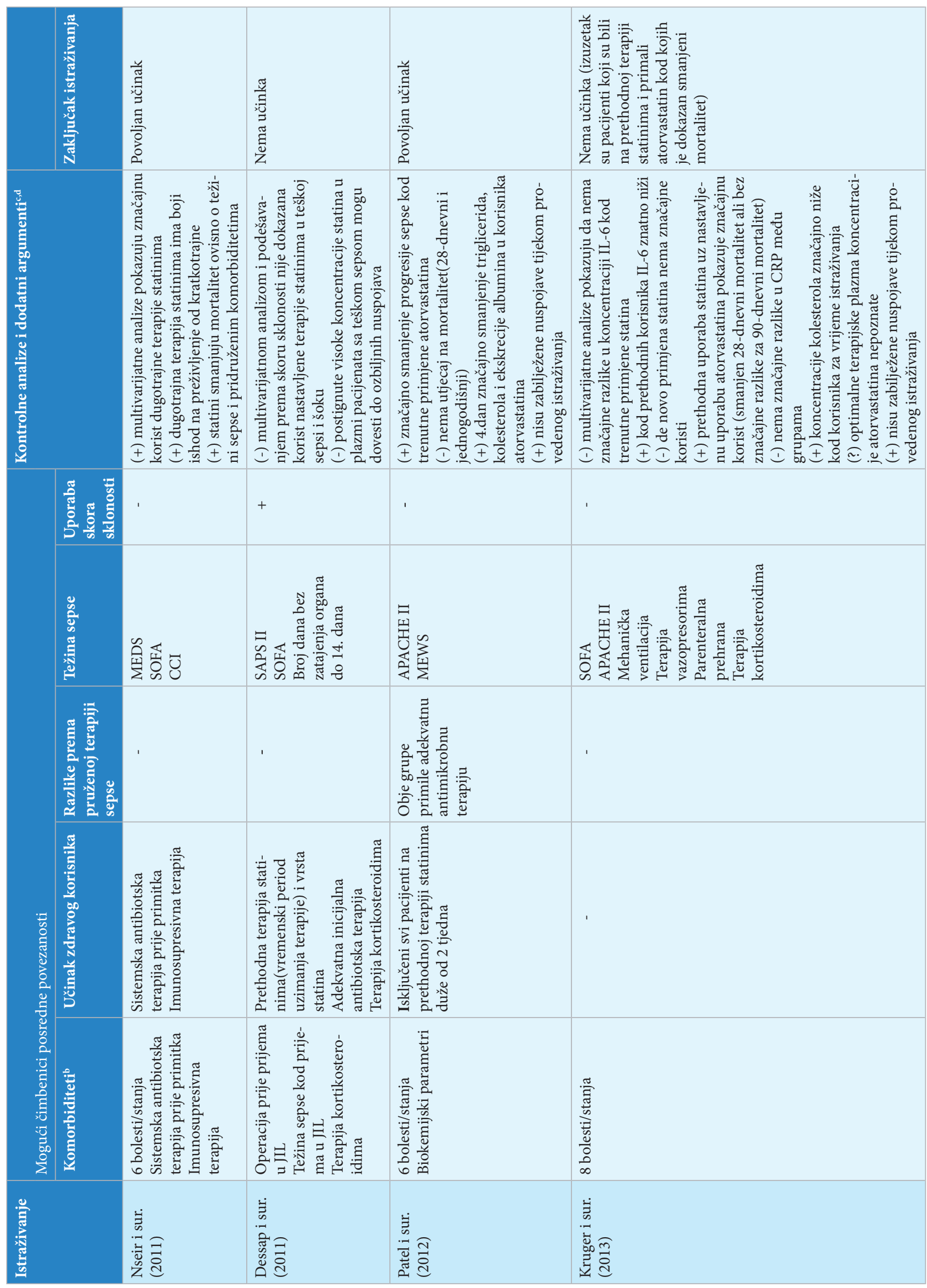




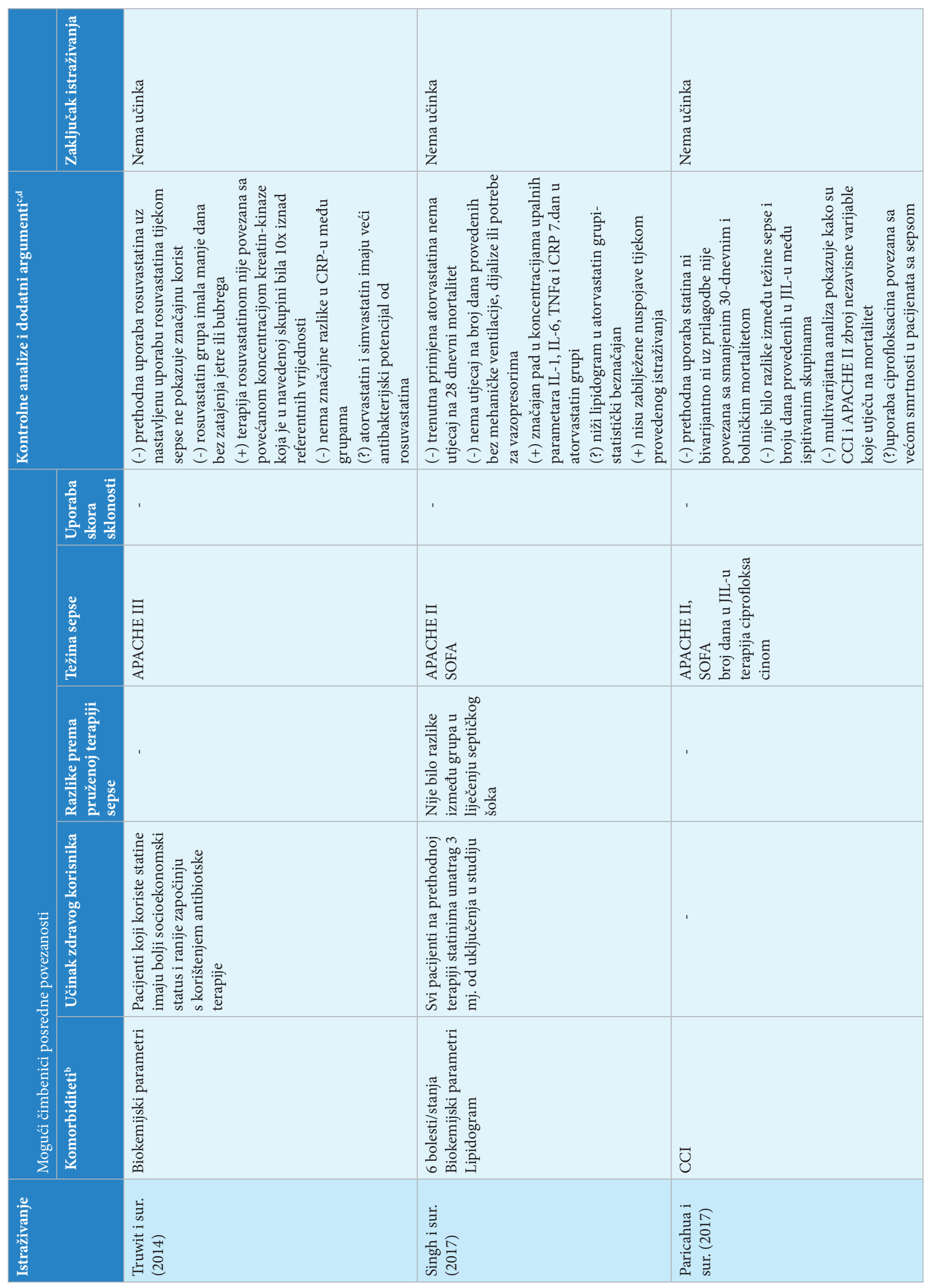



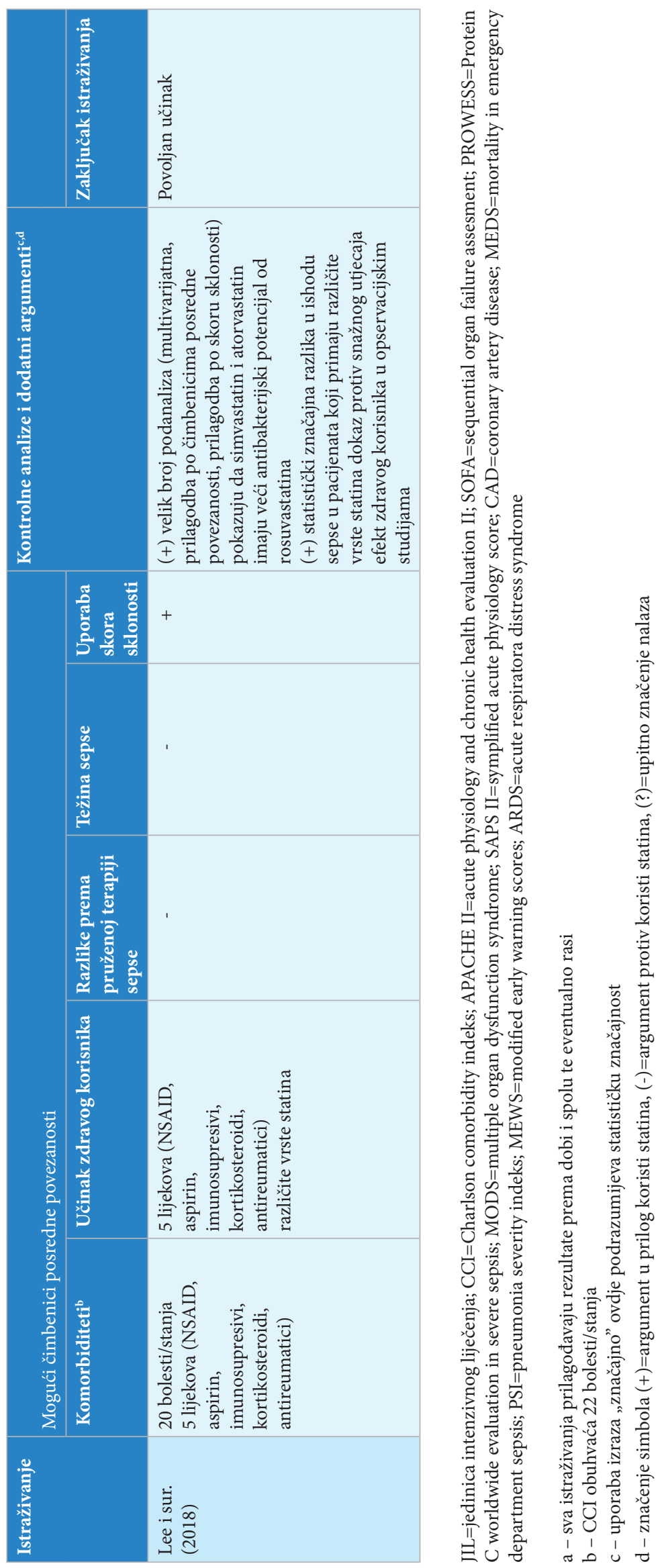


\section{Rasprava}

Glavni nalaz ovog rada je da više od polovice istraživanja koje smo proučavali (njih deset) negiraju korist statina, drugim riječima ukazuju da prethodna terapije statinima ne utječe na ishod liječenja sepse iz opće populacije i smanjenu smrtnost kod istih, dok ostalih osam ukazuju na korist statina. Jedno istraživanje (22) koje je zapravo randomizirani klinički pokus dokazao je korist trenutne primjene statina $\mathrm{u}$ prethodnih korisnika, ali ne i u de novo korisnika što daje poseban značaj ovom radu uzimajući u obzir rasprave stručnjaka o uvođenju terapije statinima u trenu hospitalizacije kod ljudi koji prethodno nisu bili na statinima. Jedno drugo istraživanje (16) dokazalo je korist trenutne primjene statina u pacijenata koji nisu bili na prethodnoj terapiji statinima, međutim nedostatak tog istraživanja je što je uključilo mali broj pacijenata koji nisu bili kritično bolesni. Također pozitivan ishod dokazan je samo za 30-dnevni mortalitet, dok kod dugoročnog nema utjecaja, dok jedno novije istraživanje (17) nije dokazalo korist trenutne primjene statina kod pacijenata koji nisu bili na prethodnoj terapiji statinima.

Moramo uzeti u obzira da su ovdje prikazana istraživanja heterogena po dizajnu, metodologiji, promatranim ishodima i kontroliranim čimbenicima posredne povezanosti, što je onemogućilo provedbu meta-analize. Provedena kvalitativna usporedba pokazuje da su istraživanja s „negativnim” rezultatom detaljnija u opsegu i kontroli čimbenika posredne povezanosti, posebno efekta zdravog korisnika, stoga možemo zaključiti da je pozitivan rezultat mogao biti zbog nedovoljne kontrole tih čimbenika. Također ograničenja pozitivnih istraživanja su mali broj ispitanika, heterogenost s obzirom na ustroj (retrospektivnost, prospektivnost), promatranja prethospitalne ili nastavljene unutarbolničke terapije statinima tijekom liječenja infekcije, zatim prema promatranim ishodima (progresija u teži oblik sepse, broj dana bez razvoja multiorganske disfunkcije, opći mortalitet, kratkoročni ili dugoročni mortalitet), kao i činjenica da nisu ispitivali razlike između pojedinih statina, zatim koliko dugo su pacijenti bili na prethodnoj terapiji i na kojoj dozi lijeka.

Ipak, ovaj rad ima i svoje kvalitete. Detaljno smo pretražili bazu podataka i sve radove na ovu temu, članke smo detaljno analizirali, kritički evaluirali, osobito što se tiče čimbenika posredne povezanosti i brojnih kontrolnih analiza. Glavna mjera ishoda koju smo promatrali, mortalitet jasno je definirana u svim istraživanjima, što nam je uz sve ostale čimbenike omogućilo da istraživanja podijelimo na ona s "pozitivnim” rezultatom i ona s, „negativnim”. Rezultati našeg istraživanja kao i većine novijih randomiziranih kliničkih studija ukazuju da nema dovoljno dokaza da se statini koriste u liječenju sepse jer ne utječu na ishod liječenja niti smanjuju mortalitet, stoga ostaje otvoreno pitanje o potrebi uvođenja statina u kliničku praksu liječenja sepse. Smatramo da su potrebna opsežnija i detaljnija istraživanja na temelju kojih bi mogli donijeti adekvatne zaključke, jer još uvijek nemamo čvrste dokaze o djelotvornosti. Buduća istraživanja trebaju imati za cilj rasvjetljavanje pitanja mogu li statini utjecati na učestalost i smrtnost od sepse, tj. pitanje bi li terapija statinima imala profilaktičku ulogu u smislu smanjenja učestalosti sepse i smanjenja učestalosti teške sepse i/ili statine ima smisla davati u terapiji novonastale sepse kako bi se modificirao upalni odgovor. Za prvu i drugu potencijalnu indikaciju treba rasvijetliti i doziranje statina. Osim toga, problem vjerojatno predstavlja i nepostojanje statina u obliku za parenteralnu primjenu, neophodnu u slučaju najteže bolesnih pacijenata koji ne mogu primati lijekove per os.

Od velike važnosti su mogući nepovoljni učinci statina u septičkih pacijenata koji ako ih ima, moraju biti ispitani. Najveće značenje dobivaju moguća oštećenja jetre i mišića. Istraživanja koja smo mi proučili nisu zabilježila nuspojave za vrijeme ispitivanja (to je posebno istaknuto u pet randomiziranih kliničkih pokusa koja smo ovdje uključili).

Na kraju želimo još malo biti kritični i zapitati se pokušavaju li farmaceutske kuće pronaći novu arenu za statine budući da su se statini pokazali relativno sigurnim lijekovima kod većine pacijenata kojima su namijenjeni. Ova pretpostavka ukazuje da će biti potrebni veliki napori istraživača kako bi pronašli prave dokaze i odgovore jesu li ovi lijekovi stvarno i klinički značajno učinkoviti u mijenjanju upalnog odgovora oboljelih.

\section{Zaključak}

Zaključno možemo reći da nešto više od polovice promatranih istraživanja govori kako prethodna terapija statinima nije povezana sa smanjenim mortalitetom i boljim ishodom u pacijenata hospitaliziranih zbog sepse. Obzirom na navedeni udio istraživanja, njihovu uglavnom retrospektivnu prirodu te različite metode kontrole varijabli koje mogu izobličiti utjecaj (confounder varijable) ne možemo donijeti jednoznačan zaključak. Postoji potreba za većim studijama i randomiziranim kontroliranim ispitivanjima kako bi se razriješilo pitanje izbora lijeka, trenutka započinjanja terapije, njenog trajanja te prikladne doze lijeka. Međutim, u bolesnika koji su prethodno uzimali statine ovu terapiju treba nastaviti, barem zbog prevencije kardiovaskularnih incidenata, dok se de novo uvođenje terapije u trenutku teške sepse trenutno ne čini opravdanim. 


\section{LITERATURA}

${ }^{[1]} \mathrm{Xu}$ J, Kochanek KD, Tejada-Vera B. Deaths: Preliminary data for 2007. National vital statistics reports; vol. 58 no. 1. Hyattsville, MD: National Center for Health Statistics. 2009.

${ }^{[2]}$ Butler J. The surviving sepsis campaign (SSC) and the emergency department. Emerg Med J 2008;25:2-3.

${ }^{[3]}$ Angus DC, Linde-Zwirble WT, Lidicker J, Clermont G, Carcillo J, Pinsky MR. Epidemiology of severe sepsis in the United States: analysis of incidence, outcome and associated costs of care. Crit Care Med 2001;29:1303-10.

${ }^{[4]}$ Kruger P, Fitzsimmons K, Cook D, Jones M, Nimmo G. Statin therapy is associated with fewer deaths in patients with bacteraemia. Intensive Care Med 2006;32(1):75-79.

${ }^{[5]}$ Rangel-Frausto MS, Pittet D, Costigan M, Hwang T, Davis CS, Wenzel RP. The natural history of the systemic inflammatory response syndrome (SIRS). A prospective study. JAMA 1995; 273(2):117-123.

${ }^{[6]}$ Almog Y. Statins, inflammation, and sepsis: hypothesis. Chest 2003;124(2):740-743.

${ }^{[7]}$ Bochud PY, Calandra T. Pathogenesis of sepsis: new concepts and implications for future treatment. BMJ 2003;326(7383): 262-266.

${ }^{[8]}$ Terblanche M, Almog Y, Rosenson RS, Smith TS, Hackam DG. Statins and sepsis: multiple modifications at multiple levels. Lancet Infect Dis 2007;7(5):358-368.

${ }^{[9]}$ Faust SN, Levin M, Harrison OB, et al. Dysfunction of endothelial protein $\mathrm{C}$ activation in severe meningococcal sepsis. N Engl J Med 2001;345(6):408-416.

${ }^{[10]}$ Balk RA. Severe sepsis and septic shock. Definitions, epidemiology, and clinical manifestations. Crit Care Clin 2000; 16(2): 179-192.

${ }^{[11]}$ Shepherd J, Cobbe SM, Ford I, et al. Prevention of coronary heart disease with pravastatin in men with hypercholesterolemia. West of Scotland Coronary Prevention Study Group. N Engl J Med 1995;333(20):1301-1307.

${ }^{[12]}$ Goldstein JL, Brown MS. Regulation of the mevalonate pathway. Nature 1990;343(6257):425-430.

${ }^{[13]}$ Halcox JP, Deanfield JE. Beyond the laboratory: clinical implications for statin pleiotropy. Circulation 2004;109(21 Suppl 1): II42-II48.

${ }^{[14]}$ Landmesser U, Bahlmann F, Mueller M, et al. Simvastatin versus ezetimibe: pleiotropic and lipid-lowering effects on endothelial function in humans. Circulation 2005;111(18):2356-2363.

${ }^{[15]}$ Sakabe K, Fukuda N, Wakayama K, Nada T, Shinohara H, Tamura Y. Lipid-altering changes and pleiotropic effects of atorvastatin in patients with hypercholesterolemia. Am J Cardiol 2004;94(4):497-500.

${ }^{[16]}$ Patel JM, Snaith C, Thickett DR, et al. Randomized doubleblind placebo-controlled trial of $40 \mathrm{mg} /$ day of atorvastatin in reducing the severity of sepsis in ward patients (ASEPSIS Trial). Crit Care 2012;16(6):R231.

${ }^{[17]}$ Singh RK, Agarwal V, Baronia AK, Kumar S, Poddar B, Azim A. The Effects of Atorvastatin on Inflammatory Responses and Mortality in Septic Shock: A Single-center, Randomized Controlled Trial. Indian J Crit Care Med 2017;21(10):646-654.

${ }^{[18]}$ Almog Y, Shefer A, Novack V, et al. Prior statin therapy is associated with a decreased rate of severe sepsis. Circulation 2004; 110(7):880-885.

${ }^{[19]}$ Lee CC, Lee MG, Hsu TC, et al. A Population-Based Cohort Study on the Drug-Specific Effect of Statins on Sepsis Outcome. Chest 2018;153(4):805-815.
${ }^{[20]}$ Thomsen RW. The lesser known effects of statins: benefits on infectious outcomes may be explained by "healthy user" effect. BMJ 2006;333(7576):980-981.

${ }^{[21]}$ Thomsen RW, Hundborg HH, Johnsen SP, et al. Statin use and mortality within 180 days after bacteremia: a population-based cohort study. Crit Care Med 2006;34(4):1080-1086.

${ }^{[22]}$ Kruger P, Bailey M, Bellomo R, et al. A multicenter randomized trial of atorvastatin therapy in intensive care patients with severe sepsis. Am J Respir Crit Care Med 2013;187(7):743-750.

${ }^{[23]}$ Yende S, Milbrandt EB, Kellum JA, et al. Understanding the potential role of statins in pneumonia and sepsis. Crit Care Med 2011;39(8):1871-1878.

${ }^{[24]}$ National Heart, Lung, and Blood Institute ARDS Clinical Trials Network, Truwit JD, Bernard GR, et al. Rosuvastatin for sepsis-associated acute respiratory distress syndrome. N Engl J Med 2014;370(23):2191-2200.

${ }^{[25]}$ Charlson ME, Pompei P, Ales KL, MacKenzie CR. A new method of classifying prognostic comorbidity in longitudinal studies: development and validation. J Chronic Dis 1987; 40(5):373-383.

${ }^{[26]}$ Glynn RJ, Schneeweiss S, Wang PS, Levin R, Avorn J. Selective prescribing led to overestimation of the benefits of lipid-lowering drugs. J Clin Epidemiol 2006;59(8):819-828.

${ }^{[27]}$ Simpson SH, Eurich DT, Majumdar SR, et al. A meta-analysis of the association between adherence to drug therapy and mortality. BMJ 2006;333(7557):15.

${ }^{[28]}$ Liappis AP, Kan VL, Rochester CG, Simon GL. The effect of statins on mortality in patients with bacteremia. Clin Infect Dis 2001;33(8):1352-1357.

${ }^{[29]}$ Nseir W, Mograbi J, Abu-Elheja O, Bishara J, Assy N. The impact of prior long-term versus short-term statin use on the mortality of bacteraemic patients. Infection 2012;40(1):41-48.

${ }^{[30]}$ Williams JM, Greenslade JH, Chu K, Brown AF, Paterson D, Lipman J. Prior statin use is not associated with improved outcome in emergency patients admitted with infection: a prospective observational study. Acad Emerg Med 2011;18(2):127-134.

${ }^{[31]}$ Paricahua LI, Goncalves AFO, Pacheco SODS, Pacheco FJ. Sepsis Mortality in Critical Care and Prior Statin Therapy: A Retrospective Cohort Study in Central Argentina. J Clin Diagn Res 2017;11(6):OC17-OC21.

${ }^{[32]}$ Kruger PS, Freir NM, Venkatesh B, Robertson TA, Roberts MS, Jones M. A preliminary study of atorvastatin plasma concentrations in critically ill patients with sepsis. Intensive Care Med 2009;35(4):717-721.

${ }^{[33]}$ Schmidt H, Hennen R, Keller A, et al. Association of statin therapy and increased survival in patients with multiple organ dysfunction syndrome. Intensive Care Med 2006;32(8):1248-1251.

${ }^{[34]}$ Yang KC, Chien JY, Tseng WK, Hsueh PR, Yu CJ, Wu CC. Statins do not improve short-term survival in an oriental population with sepsis. Am J Emerg Med 2007;25(5):494-501.

${ }^{[35]}$ Goodin J, Manrique C, Dulohery M, Sampson J, Saettele M, Dabbagh O. Effect of statins on the clinical outcomes of patients with sepsis. Anaesth Intensive Care 2011;39(6):1051-1055.

${ }^{[36]}$ Kruger PS, Harward ML, Jones MA, et al. Continuation of statin therapy in patients with presumed infection: a randomized controlled trial. Am J Respir Crit Care Med 2011;183(6):774-781.

${ }^{[37]}$ Mekontso Dessap A, Ouanes I, Rana N, et al. Effects of discontinuing or continuing ongoing statin therapy in severe sepsis and septic shock: a retrospective cohort study. Crit Care 2011;15(4):R171. 